\title{
Use and implementation of the International Classification of Functioning, Disability and Health with Children and Youth within the context of Augmentative and Alternative Communication: an integrative literature review
}

Universidade Estadual de Campinas UNICAMP, Faculdade de Ciências Médicas, Campinas, São Paulo, Brasil.

San Francisco State University, Departamento de Educação Especial, São Francisco, Estados Unidos.

University College London, Ciência de Psicologia e Linguagem, Linguagem e Cognição, Londres, Inglaterra.

Research support source: Coordenação de Aperfeiçoamento de

Pessoal de Nivel Superior - CAPES (99999.003548/2015-05)

Conflict of interests: Nonexistent

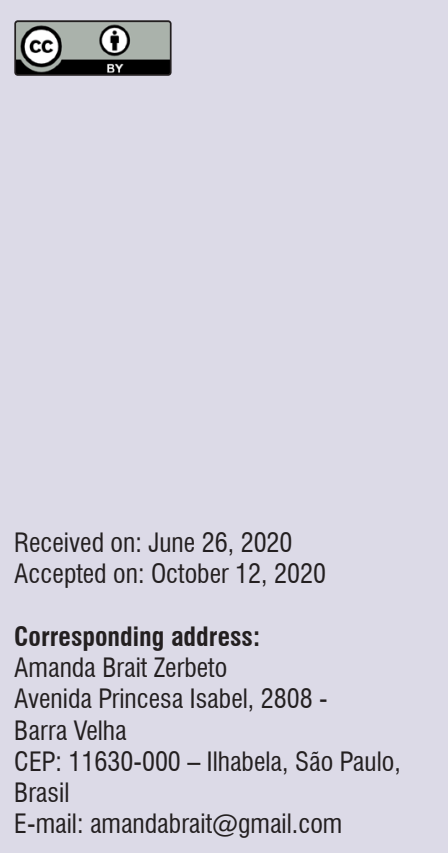

Amanda Brait Zerbeto ${ }^{1}$ https://orcid.org/0000-0003-3411-6856

Gloria Soto ${ }^{2}$ https://orcid.org/0000-0002-3254-3099

Regina Yu Shon Chun ${ }^{1}$ https://orcid.org/0000-0002-5305-7081

Maria de Lurdes Zanolli' https://orcid.org/0000-0001-7419-8257

Ana Carolina Franzolin Araujo Rezende ${ }^{1}$ https://orcid.org/0000-0001-6621-8035

Michael Clarke ${ }^{3}$ https://orcid.org/0000-0002-8933-8934

\section{ABSTRACT}

Purpose: to discuss the implementation and use of the International Classification of Functioning, Disability and Health (ICF) and International Classification of Functioning, Disability and Health, Children and Youth Version (ICF-CY) among children and adolescents, within the Augmentative and Alternative Communication (AAC) field.

Methods: an integrative literature review. PubMed, Web of Science and VHL databases were searched for papers published between 2006 and 2017 that reported on the use of ICF and ICF-CY within the AAC context. Eighteen papers were reviewed and sorted into: Category i) papers which reported on the use of the ICF or ICF-CY with people who rely on AAC; and Category ii) theoretical papers or papers that used the ICF and ICF-CY to organize the results.

Results: papers used the frameworks with different purposes, including the characterization of the children and their environment, goal setting and measurement of the results of therapeutic intervention. The papers drew on all elements, however, Activities and Participation were the components most used. Parents or caregivers were most commonly consulted in classifying the children's and young people's profiles of functioning, followed by the Educators and speech and language pathologists.

Conclusion: classifications have shown advantages when used in the AAC field. Therefore, it is necessary to provide training in order for professionals to implement them in services.

Keywords: International Classification of Functioning, Disability and Health; Communication Barriers; Social Participation; Child; Adolescent 


\section{INTRODUCTION}

The biopsychosocial model of the International Classification of Functioning, Disability and Health, ICF ${ }^{1}$ and of the International Classification of Functioning, Disability and Health, Children and Youth Version, ICF-CY2 has been increasing its influence in the Augmentative and Alternative Communication (AAC) field ${ }^{3.5}$. These two frameworks subscribe a biopsychosocial model of disability. The ICF and ICF-CY models view health, health-related conditions and their consequences in daily life, and present a framework to determine factors that could be modified to improve the communication and participation of those who experience them ${ }^{1,2,4-6}$. The ICF is part of the World Health Organization, WHO Family of International Classifications and was created to complement the International Statistical Classification of Diseases and Related Health Problems 10th revision, ICD-107. The ICF classifies health outcomes while ICD-10 classifies morbidity data, based on diagnoses of diseases and health problems. ICF-CY was created with the purpose of including key elements relevant to the characterization of children and youth. The ICF-CY includes new classifications that are particularly relevant to describing communication in children and young people that use $A A C$, including eye contact, preverbal vocalization, pointing, turn taking and equipment, products, and technologies used by children in playing and learning. In 2015, in Brazil, the International Classification of Functioning, Disability and Health (ICF) and its version for children and young people (ICF-CY) were merged.

The main goals of the ICF and ICF-CY are to provide a unified and standardized language and point of reference for the description of the client's health, in addition to establishing a common language to facilitate the development of the capability-oriented databases ${ }^{1,2}$. More broadly the ICF and ICF-CY can be used as (a) a statistical tool (in the collection and recording of data), (b) a research tool (in the measurement of outcomes, and characterization of the participants), (c) a clinical tool (to guide assessment, goal setting, and intervention etc), (d) a social security tool (in social security planning, and policy design); and (e) an educational tool (in curriculum design and to raise awareness of disability issues) $)^{1,2}$.

ICF and ICF-CY are composed of specific codes that are applied to parts and components to provide a classification. In structural terms, the ICF and ICF-CY are composed of two parts, each with two elements ${ }^{1,2}$. In Part 1 , functioning and disability are considered.
The Body component is classified into Body Function and Body Structure and describes items such as mental, voice, and speech functions and structures. Activities and Participation describe functioning, including communication, interpersonal interactions, self-care, learning and applying knowledge. In Part 2, factors related to context are considered, which can be environmental and personal. Environmental Factors are those considered not to be directly within the person's control, but have an impact on all components of functioning and disability, such as family, school, laws, and cultural beliefs. Environmental Factors can be facilitators or barriers, influencing functionality positively or negatively. Personal Factors include race, gender, age, educational level etc, but these items are not specifically coded in the ICF because of the wide variability among cultures. All of the components interact with each other (Figure 1), so the disability can be understood as an interaction between the physiological problems and the social environment.

Each of the ICF components can be expressed in positive or negative terms, thus, the ICF is not restricted only to negative aspects, but also documents the positive aspects of functioning ${ }^{1,2}$. The levels of difficulty observed in the individual and the environment are expressed by qualifiers. In Part 1 , the qualifiers range from level 0 (zero) corresponding to no problem or difficulty to level 4 , which means a total or complete limitation. In relation to Environmental Factors, the qualifiers can be considered as facilitators (with a "+" symbol next to the numeric code) or barriers (with a point after the numeric code). Thus, a given environmental factor can be considered as no obstacle (.0) to total obstacle (.4), or, on the other hand, no facilitator $(+0)$ to total facilitator $(+4)$.

The ICF and ICF-CY have grown in popularity of use in the AAC field because they contain domains that are important for description of AAC users and their environments. The domains reflect the multi-dimensional nature of communication and the interaction between the person and their social and physical environment ${ }^{8,9}$. A second benefit of the ICF to the AAC field is that it offers a common inter-professional language. The ICF and ICF-CY may enhance communication among professionals, and among professionals and parents ${ }^{4,9}$. A third advantage is that the models are applicable across different elements of client management such as assessment, goal setting, and outcome evaluation of AAC interventions $\mathbf{s}^{8-10}$. 


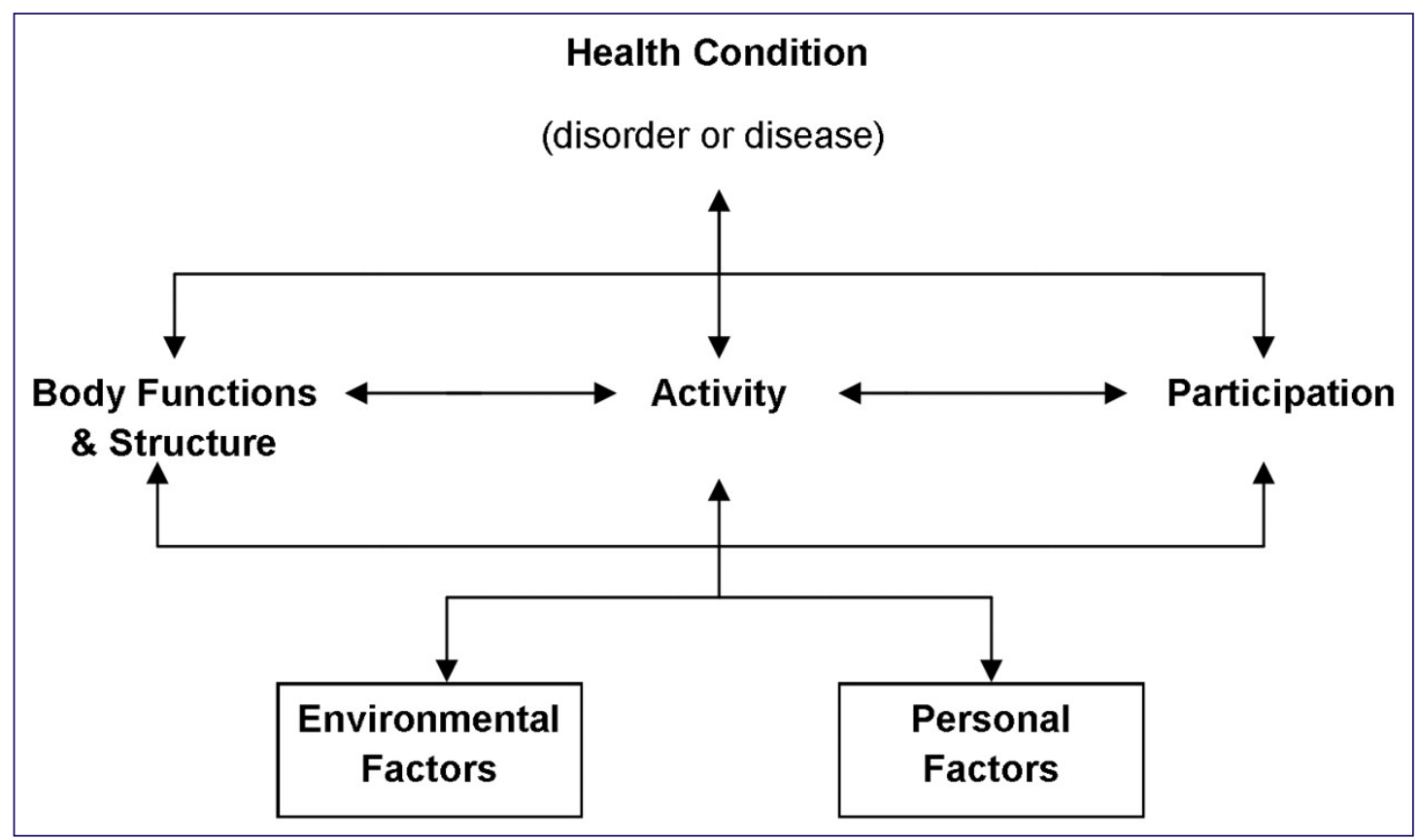

From ICF International Classification of Functioning, Disability and Health, by the World Health Organization, 2001.

Figure 1. The International Classification of Functioning, Disability and Health (WHO, 2001)

A communication impairment can manifest at different levels of severity and in a variety of ways for each person ${ }^{9}$, and ICF frameworks may assist professionals to consider items from a range of interdependent dimensions that need to be assessed and may be the focus of goals for intervention. For instance, consideration may first be given to the different dimensions of the communication including factors related to Body Functions \& Structures, different communicative partners, and contexts in which communication happens. Secondly, Environment Factors that influence communication can be documented (e.g., personal support and personal relationships, availability of AAC system, attitudes toward assistive communication device). Thirdly, the extent to which the individual can engage in various activities may be reported (to listen, being alert, receptive and expressive language, reading, writing, interaction, pragmatic skills, vocabulary selection, visual demands, motor demands, auditory demands). Fourthly, how and with whom the person participates in these activities (interaction with family, extended family, friends, teachers, strangers, significant others; interaction in tasks; general participation in society). Together, these domains of description provide a holistic view of the client ${ }^{4,11}$ and promote the development of individualized interventions ${ }^{5}$. As such, the ICF and ICF-CY de-emphasize the impairment and emphasize the client's functioning ${ }^{9}$.

Given the growing significance of the ICF and ICF-CY in assessment and intervention planning across domains of disability, the purpose of this article is to discuss the implementation and use of the ICF and the ICF-CY with children and adolescents, within the context of AAC including the viability in use these frameworks in the clinical practice which components were most frequently used in the papers. Specifically, the implementation of ICF and ICF-CY in the AAC field will be examined according to the following items: (i) clinical purpose of use the framework, (ii) instruments created based on the frameworks, and (iii) methods used to classify ICF / ICF-CY components, use of qualifiers, disadvantages and advantages of the use of ICF and ICF-CY in the AAC field.

\section{METHODS}

\section{Search strategies}

The integrative review followed six steps: elaboration of the guiding question, literature research, data collection, data analysis, discussion of the results and presentation of the integrative review. The research was guided by this guiding question: How are the ICF and 
the ICF-CY being implemented and used with children and adolescents, within the AAC context?

\section{Selection criteria}

PubMed, Web of Science and Virtual Health Library (VHL) databases were searched for papers published between 1 January 2006 and 30 September 2017 that reported the use of ICF and ICF-CY within the context of AAC. The bibliographical references of the selected papers were manually scanned, and articles that did not appear in the databases were included if they met specific inclusion and exclusion criteria (described in Figure 2). The following keywords were used in the searches: International Classification of Functioning, Disability and Health AND Augmentative and Alternative Communications Systems, International Classification of Functioning, Disability and Health AND Communication Complex Needs, ICF-CY AND Communication Complex Needs, ICF-CY AND Augmentative and Alternative Communications Systems, Disabled children AND Augmentative alternative communication systems, CIF AND Comunicação Suplementar Alternativa, CIF-CJ AND Comunicacao Suplementar Alternativa, Funcionalidade AND Comunicação Suplementar Alternativa, CIF AND CSA, CIF-CJ AND CSA.

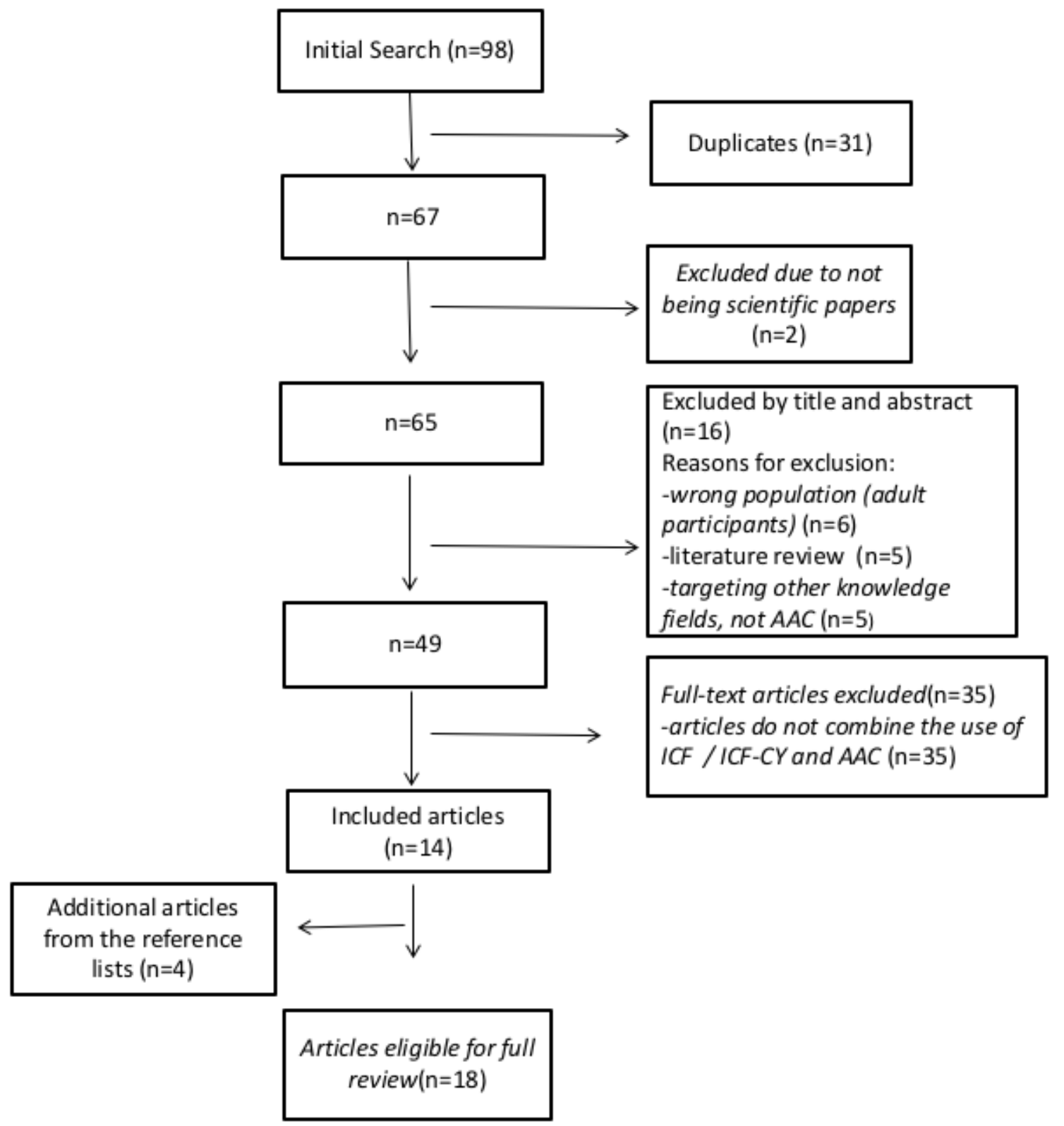

Figure 2. Study selection flow diagram 
Inclusion Criteria: To be included in the review, studies had to (1) describe the use of ICF or ICF-CY with children and adolescents who use AAC, (2) the use of instruments elaborated with the ICF and ICF-CY principles, or (3) discuss the use of ICF or ICF-CY in the AAC field. In addition, they had to be published in peer-refereed journals; written in English or in Portuguese; and include children and adolescents, with any type of disability. Studies were excluded if they reported the use of these frameworks with adults or seniors or if they used an integrative review method using the ICF or ICF-CY in purpose.

\section{Data analysis}

98 results were found in the PubMed, Web of Science and BVS databases in the selected period of time, of which 31 were excluded because they were duplicated. Of the remaining 67 results, two were excluded because they were not scientific papers. 16 papers were excluded from the integrative review after reading the title and abstract because they did not meet the inclusion criteria (participants were adults, review literature, and papers belong to another knowledge field like genetics). The remaining 49 papers were read in full, and 14 were selected to be analyzed in the integrative review. Another four papers were included after reading the 14 selected papers' references.

18 papers were reviewed in detail. The papers were sorted into two Categories. Category i) papers which reported the use of the ICF or ICF-CY with people who rely on $A A C$, and papers in the $A A C$ field which elaborated or used an instrument based on the ICF or ICF-CY frameworks (Figure 3); and Category ii) theoretical papers which discussed the use of the ICF or ICF-CY in the AAC field, or used the ICF and ICF-CY to organize results (Figure 4). The Evidence Based Medicine tool from the Oxford Center was used to assess the methodological quality and classify the evidence levels of the final selection of studies (https:// www.cebm.net/2009/06/oxford-centre-evidence-based-medicine-levels-evidence-march-2009/) ${ }^{22}$.

\begin{tabular}{|c|c|c|c|c|c|c|c|}
\hline Reference & Purpose of paper & $\begin{array}{l}\text { Study design/ } \\
\text { Levels of } \\
\text { evidence (22) }\end{array}$ & $\begin{array}{l}\text { Diagnosis of } \\
\text { participants }\end{array}$ & $\begin{array}{c}\text { Instruments } \\
\text { based on the ICF } \\
\text { / ICF-CY }\end{array}$ & $\begin{array}{l}\text { Method used } \\
\text { to classify }\end{array}$ & $\begin{array}{c}\text { People } \\
\text { consulted }\end{array}$ & Main results related to ICF/ICF-CY \\
\hline $\begin{array}{l}\text { Bornman } \\
\text { \& Murphy, } \\
\text { 2006 }\end{array}$ & \begin{tabular}{|l|} 
To suggest how \\
Talking Mats@ \\
can be used in \\
accordance with the \\
ICF proposed by the \\
WHO when setting \\
intervention goals
\end{tabular} & $\begin{array}{c}\text { Theoretical } \\
\text { study/ } 5\end{array}$ & $\begin{array}{c}\text { Dyspraxia and } \\
\text { aphasia }\end{array}$ & None & Interview & Clients & $\begin{array}{l}\text { Talking Mats@ can be seen as a } \\
\text { strategy through which individuals can } \\
\text { be empowered to participate in a goal- } \\
\text { setting activity. The information collected } \\
\text { will facilitate the development of person- } \\
\text { centered rehabilitation programs tailored } \\
\text { to meet the unique goals of people with } \\
\text { disabilities the best way possible }\end{array}$ \\
\hline $\begin{array}{l}\text { Hidecker } \\
\text { et al., } \\
2011^{(18)}\end{array}$ & \begin{tabular}{l|} 
To create and \\
validate the CFCS \\
for children with \\
CP, to be used \\
by a variety of \\
practitioners dealing \\
with individuals \\
with CP
\end{tabular} & $\begin{array}{c}\text { Quasi- } \\
\text { experimental } \\
\text { cross- } \\
\text { sectional/ 2C }\end{array}$ & $\mathrm{CP}$ & $\begin{array}{l}\text { Communication } \\
\text { Function } \\
\text { Classification } \\
\text { System (CFCS; } \\
\text { (Hidecker et al., } \\
\text { 2011) }\end{array}$ & $\begin{array}{l}\text { CFCS (the } \\
\text { methods that } \\
\text { participants } \\
\text { used to } \\
\text { classify were } \\
\text { not specified) }\end{array}$ & \begin{tabular}{|c|} 
Parents of \\
children with \\
CP, educators, \\
occupational \\
therapists, \\
physical \\
therapists, \\
physicians, \\
and SLP
\end{tabular} & $\begin{array}{l}\text { CFCS is an efficient instrument that can } \\
\text { help practitioners classifying the ICF level } \\
\text { of individuals with CP. Building on the } \\
\text { conceptual foundation of the ICF, functional } \\
\text { patterns may be due to differing aspects } \\
\text { of the person and contextual factors. A } \\
\text { relevant result was that practitioners tended } \\
\text { to classify the child's communication } \\
\text { function as less effective than the parents' } \\
\text { classification. Parents are likely to observe } \\
\text { their children in more environments } \\
\text { interacting with several communication } \\
\text { partners. At the same time, parents } \\
\text { may underestimate difficulties faced by } \\
\text { unfamiliar communication partners who } \\
\text { communicate with their children }\end{array}$ \\
\hline $\begin{array}{l}\text { Clarke et al., } \\
2012^{(12)}\end{array}$ & \begin{tabular}{|l|} 
To examine variation \\
in the frequency \\
of children's \\
participation in out- \\
of-school activities \\
as a function of \\
speech intelligibility, \\
perceived \\
effectiveness \\
of the child's \\
communication aid, \\
and age
\end{tabular} & $\begin{array}{l}\text { Descriptive } \\
\text { cross- } \\
\text { sectional/4 }\end{array}$ & $\begin{array}{l}\text { CP, autism, } \\
\text { dyspraxia, } \\
\text { learning } \\
\text { disabilities }\end{array}$ & None & Questionnaire & Caregivers & $\begin{array}{l}\text { Partial correspondence between the CAPE } \\
\text { items and the ICF-CY activity domains } \\
\text { provides some scope for reflecting on } \\
\text { the current findings in the context of } \\
\text { the ICF-CY. Younger children who have } \\
\text { some intelligible speech display a higher } \\
\text { frequency of participation than young } \\
\text { children without speech and older children. } \\
\text { That is particularly evident in social and } \\
\text { recreational participation }\end{array}$ \\
\hline
\end{tabular}




\begin{tabular}{|c|c|c|c|c|c|c|c|}
\hline Reference & Purpose of paper & $\begin{array}{l}\text { Study design/ } \\
\text { Levels of } \\
\text { evidence (22) }\end{array}$ & $\begin{array}{l}\text { Diagnosis of } \\
\text { participants }\end{array}$ & $\begin{array}{c}\text { Instruments } \\
\text { based on the ICF } \\
\text { / ICF-CY }\end{array}$ & $\begin{array}{l}\text { Method used } \\
\text { to classify }\end{array}$ & $\begin{array}{c}\text { People } \\
\text { consulted }\end{array}$ & Main results related to ICF/ICF-CY \\
\hline $\begin{array}{l}\text { Delarosa } \\
\text { et al., 2012(3) }\end{array}$ & \begin{tabular}{|l|} 
To describe the \\
development and \\
evaluation of the \\
FIATS for AAC \\
Systems - a parent- \\
report questionnaire \\
intended to detect \\
the impact of AAC \\
systems on the \\
lives of children \\
with complex \\
communication \\
needs and their \\
families
\end{tabular} & $\begin{array}{c}\text { Quasi- } \\
\text { experimental } \\
\text { cross- } \\
\text { sectional/ } 2 \mathrm{C}\end{array}$ & $\begin{array}{c}\mathrm{CP} \text {, autism, } \\
\text { developmental } \\
\text { delay }\end{array}$ & $\begin{array}{l}\text { Family Impact of } \\
\quad \text { Assistive } \\
\text { Technology Scale } \\
\text { for Augmentative } \\
\text { and Alternative } \\
\text { Communication } \\
\text { (FIATS-AAC) }\end{array}$ & Questionnaire & Parents & $\begin{array}{l}\text { Assistive technology research teams } \\
\text { contend that evidence supporting the } \\
\text { positive influence of AAC systems on the } \\
\text { functional performance of children with } \\
\text { CCN and their families is consistently } \\
\text { positive but lacks empirical credibility. It is } \\
\text { arguably more important to recognize the } \\
\text { FIATS-AAC as an emerging inventory of } \\
\text { key measures that may enlighten aspects } \\
\text { of child and family functioning influenced } \\
\text { by the introduction of AAC systems }\end{array}$ \\
\hline $\begin{array}{l}\text { Raghavendra } \\
\text { et al., } 2012 \\
\text { (13) }\end{array}$ & \begin{tabular}{|l|} 
To describe and \\
compare the school \\
participation and \\
social networks \\
of children with \\
physical disabilities \\
and complex \\
communication \\
needs (Group \\
CCN), children with \\
physical disabilities \\
only (Group PD), \\
and children with \\
typical development \\
(Group TD) \\
\end{tabular} & $\begin{array}{l}\text { Multi-group } \\
\text { cross- } \\
\text { sectional/ } 4\end{array}$ & $\begin{array}{l}\text { CP, syndrome, } \\
\text { spina bifida }\end{array}$ & $\begin{array}{l}\text { Communication } \\
\text { Function } \\
\text { Classification } \\
\text { System (CFCS; } \\
\text { Hidecker } \\
\text { et al., 2011) }\end{array}$ & $\begin{array}{c}\text { Observation } \\
\text { and interview }\end{array}$ & $\begin{array}{l}\text { School staff, } \\
\text { parents } \\
\text { and/or child }\end{array}$ & $\begin{array}{l}\text { Group CCN participants did the same } \\
\text { activities as their peers less frequently. } \\
\text { They received more adult support than } \\
\text { did the other two groups. Group CCN did } \\
\text { not use their aided AAC in classrooms, } \\
\text { limiting their capacity to share, comment, } \\
\text { question, and contribute academically and } \\
\text { socially. Group CCN participants also had } \\
\text { fewer acquaintances than did participants } \\
\text { in Groups PD and TD. The participation } \\
\text { restrictions identified and the contextual } \\
\text { factors involved suggest directions for } \\
\text { interventions }\end{array}$ \\
\hline $\begin{array}{l}\text { Rownland } \\
\text { et al., } \\
2012^{(14)}\end{array}$ & \begin{tabular}{l|} 
To describe the ICF- \\
CY for AAC Profile, \\
a tool to integrate \\
information about \\
the multiple \\
factors affecting \\
communication \\
skill development \\
and use in school- \\
aged children \\
with complex \\
communication \\
needs \\
\end{tabular} & $\begin{array}{c}\text { Quasi- } \\
\text { experimental } \\
\text { cross- } \\
\text { sectional/ 2C }\end{array}$ & $\begin{array}{l}\text { (Fictional } \\
\text { reports) }\end{array}$ & $\begin{array}{l}\text { Communication } \\
\text { Supports } \\
\text { Inventory- } \\
\text { Children \& Youth } \\
\text { (CSI-CY; Rowland } \\
\text { et al., 2012) }\end{array}$ & Not applicable & $\begin{array}{l}\text { SLPs and } \\
\text { educators }\end{array}$ & $\begin{array}{l}\text { This tool may move the AAC community to } \\
\text { consider a broader view of environmental } \\
\text { factors which influence a student's set } \\
\text { of communication skills. The proposed } \\
\text { ICF-CY for AAC Profile provides a } \\
\text { developmental framework with the flexibility } \\
\text { to accommodate change, thus maintaining } \\
\text { relevance as the child develops and } \\
\text { transitions from one school environment } \\
\text { to another }\end{array}$ \\
\hline $\begin{array}{l}\text { Bunning } \\
\text { et al., } \\
2014^{(19)}\end{array}$ & \begin{tabular}{|l|} 
To investigate \\
preliminary \\
evidence of the \\
impact associated \\
with a home- \\
based, caregiver- \\
implemented \\
intervention \\
employing AAC \\
methods \\
\end{tabular} & $\begin{array}{c}\text { Qualitative } \\
\text { Iongitudinal/ } 4\end{array}$ & $\begin{array}{l}\text { CP, autism, } \\
\text { syndrome, } \\
\text { intellectual } \\
\text { disability } \\
\text { and hearing } \\
\text { impairment }\end{array}$ & $\begin{array}{c}\text { Communication } \\
\text { Profile-Adapted } \\
\text { (CP-A; Bunning } \\
\text { et al., 2014) }\end{array}$ & Interview & Caregivers & $\begin{array}{l}\text { The data provided evidence of statistically } \\
\text { significant positive changes in caregiver } \\
\text { perceptions of communication at the } \\
\text { levels of Body Structure and Function, } \\
\text { and Activities for Communication. } \\
\text { Also, analysis of the Participation for } \\
\text { Communication section revealed some } \\
\text { expansion to the children's social activities }\end{array}$ \\
\hline $\begin{array}{l}\text { Romano } \\
\text { \& Chun, } \\
2014^{(20)}\end{array}$ & $\begin{array}{l}\text { To investigate } \\
\text { language issues, } \\
\text { participation and } \\
\text { performance/ } \\
\text { functionality of } \\
\text { children using } \\
\text { AAC in cognitive- } \\
\text { linguistic activities } \\
\text { by means of } \\
\text { components of } \\
\text { the ICF }\end{array}$ & $\begin{array}{c}\text { Qualitative } \\
\text { Iongitudinal/ } 4\end{array}$ & $\begin{array}{c}\text { Down } \\
\text { syndrome, } \\
\text { developmental } \\
\text { delay, oral } \\
\text { language } \\
\text { disorder }\end{array}$ & None & $\begin{array}{c}\text { Observation } \\
\text { and analysis of } \\
\text { records }\end{array}$ & SLPS & $\begin{array}{l}\text { All participants presented changes in } \\
\text { cognitive-linguistic conditions, participation } \\
\text { and functionality. Over time, it was } \\
\text { observed a decrease in the severity } \\
\text { degree or in the barriers that the problems } \\
\text { represented for the children. The use of } \\
\text { the ICF allowed analysis of functionality } \\
\text { particularities and children participation } \\
\text { in different times, situations and contexts, } \\
\text { showing that the functionality of an } \\
\text { individual in a specific field is resulting } \\
\text { from the interaction between health } \\
\text { condition and contextual factors }\end{array}$ \\
\hline
\end{tabular}




\begin{tabular}{|c|c|c|c|c|c|c|c|}
\hline Reference & Purpose of paper & $\begin{array}{l}\text { Study design/ } \\
\text { Levels of } \\
\text { evidence (22) }\end{array}$ & $\begin{array}{l}\text { Diagnosis of } \\
\text { participants }\end{array}$ & \begin{tabular}{|c|} 
Instruments \\
based on the ICF \\
/ ICF-CY
\end{tabular} & $\begin{array}{l}\text { Method used } \\
\text { to classify }\end{array}$ & $\begin{array}{c}\text { People } \\
\text { consulted }\end{array}$ & Main results related to ICF/ICF-CY \\
\hline $\begin{array}{l}\text { Mei et al., } \\
2015^{(6)}\end{array}$ & $\begin{array}{l}\text { To explore parents' } \\
\text { views of the } \\
\text { activities and } \\
\text { participation of } \\
\text { children with CP } \\
\text { with a range of } \\
\text { communicative } \\
\text { abilities and the } \\
\text { factors (personal } \\
\text { and } \\
\text { environmental) that } \\
\text { influenced these }\end{array}$ & $\begin{array}{l}\text { Qualitative } \\
\text { cross- } \\
\text { sectional/ } 4\end{array}$ & $\mathrm{CP}$ & None & Interview & Parents & $\begin{array}{l}\text { The ICF-CY provided a valuable } \\
\text { framework for describing the activities } \\
\text { and participation of children with CP with } \\
\text { communication disorders, emphasizing } \\
\text { its clinical relevance. Key barriers } \\
\text { identified included aspects of parents' own } \\
\text { interactions with their children (e.g. not } \\
\text { offering choices), unfamiliar people and } \\
\text { settings, negative attitudes of others and } \\
\text { children's frustration. Facilitators included } \\
\text { support received from the child's family } \\
\text { and school, being amongst children, having } \\
\text { a familiar routine and the child's positive } \\
\text { disposition. AAC devices were identified as } \\
\text { both facilitators and barriers }\end{array}$ \\
\hline $\begin{array}{l}\text { Klang et al., } \\
2016^{(16)}\end{array}$ & $\begin{array}{l}\text { To explore the } \\
\text { contents of } \\
\text { communication- } \\
\text { related goals in } \\
\text { IEPs for students } \\
\text { with complex } \\
\text { communication } \\
\text { needs }\end{array}$ & $\begin{array}{l}\text { Retrospective } \\
\text { documental/4 }\end{array}$ & $\begin{array}{l}\text { Autism, CP, } \\
\text { intellectual } \\
\text { disability }\end{array}$ & \begin{tabular}{|c|} 
Communication \\
Supports \\
Inventory- \\
Children \& Youth \\
(CSI-CY; Rowland \\
et al., 2012)
\end{tabular} & Not applicable & Not applicable & $\begin{array}{l}\text { While the IEP goals contain information } \\
\text { related to several components of the ICF- } \\
\text { CY, there are few goals that foster social } \\
\text { participation. The IEPs contain a relatively } \\
\text { small proportion of goals that focus on } \\
\text { interaction with others, or classroom } \\
\text { participation and leisure activities. This } \\
\text { suggests an individual focus in terms } \\
\text { of intervention outcomes rather than a } \\
\text { societal focus, which would include the } \\
\text { child's participation in activities that are } \\
\text { meaningful and that involve interaction with } \\
\text { other peers and adults }\end{array}$ \\
\hline $\begin{array}{l}\text { Rowland } \\
\text { et al., } \\
2016^{(15)}\end{array}$ & $\begin{array}{l}\text { To determine the } \\
\text { effect of using the } \\
\text { CSI-CY on IEP } \\
\text { goals for students } \\
\text { with CCN and to } \\
\text { evaluate consumer } \\
\text { satisfaction }\end{array}$ & $\begin{array}{l}\text { Case-control } \\
\text { cross- } \\
\text { sectional/ 1B }\end{array}$ & \begin{tabular}{|c|} 
Autism, multiple \\
disabilities, \\
Down \\
syndrome, CP \\
and deaf/hard of \\
hearing
\end{tabular} & \begin{tabular}{|} 
Communication \\
Supports \\
Inventory- \\
Children \& Youth \\
(CSI-CY; Rowland \\
et al., 2012)
\end{tabular} & $\begin{array}{l}\text { CSI-CY (the } \\
\text { methods that } \\
\text { participants } \\
\text { used to } \\
\text { classify were } \\
\text { not specified) }\end{array}$ & $\begin{array}{l}\text { SLPs, special } \\
\text { education } \\
\text { teachers }\end{array}$ & $\begin{array}{l}\text { The code set basis of the CSI-CY extends } \\
\text { the common language of the ICF-CY to } \\
\text { practical educational use for children with } \\
\text { CCN across diagnostic groups. The CSI-CY } \\
\text { is well regarded as an instrument to inform } \\
\text { the content of communication goals related } \\
\text { to CCN }\end{array}$ \\
\hline
\end{tabular}

AAC- Augmentative and Alternative Communication; ICF- International Classification of Functioning, Disability and Health; ICF-CY- International Classification of Functioning, Disability and Health- version for Children and Youth; WHO- World Health Organization; CP-Cerebral Palsy; CFCS- Communication Function Classification System; CAPE- Children's Assessment of Participation and Enjoyment; CP-A- Communication Profile-Adapted; CSI-CY -Communication Supports Inventory-Children \& Youth; FIATS- Family Impact of Assistive Technology Scale; IEP- Individualized Education Programs; SLP- Speech-Language Pathologist.

Figure 3. Description of papers of category $i$ 


\begin{tabular}{|c|c|c|c|c|}
\hline References & Purpose of paper & $\begin{array}{c}\text { Levels of } \\
\text { evidence } \\
\end{array}$ & Advantages using it in the $A A C$ field & $\begin{array}{l}\text { Disadvantages/ difficulty using it in } \\
\text { AAC field }\end{array}$ \\
\hline $\begin{array}{l}\text { Pennington } \\
\text { et al., } 2007^{(8)}\end{array}$ & $\begin{array}{l}\text { To review the information } \\
\text { commonly given about AAC } \\
\text { research participants and } \\
\text { presents guidelines for the } \\
\text { description of AAC users, their } \\
\text { conversation partners and their } \\
\text { communicative environments }\end{array}$ & 5 & $\begin{array}{l}\text { - ICF contains domains that are important for the description of AAC } \\
\text { research participants and their environments. } \\
\text { - To evaluate the outcome of AAC interventions. } \\
\text { - To facilitate discussion between researchers and clinicians across } \\
\text { different disciplines, working in different types of services, in different } \\
\text { countries }\end{array}$ & $\begin{array}{l}\text { - ICF does not facilitate description } \\
\text { of communication partners and } \\
\text { this information would remain } \\
\text { supplementary to ICF. } \\
\text { - The coding of Activity, participation } \\
\text { and Environment is currently not } \\
\text { regulated by WHO }\end{array}$ \\
\hline $\begin{array}{l}\text { Raghavendra } \\
\text { et al., } 2007^{(5)}\end{array}$ & $\begin{array}{l}\text { To propose what the ICF has } \\
\text { to offer to the AAC field, from } \\
\text { both a clinical and research } \\
\text { perspective }\end{array}$ & 5 & $\begin{array}{l}\text { - The three levels of functioning according to ICF interact with aspects } \\
\text { of the AAC system in determining the function of a person. } \\
\text { - The unified and standard language used in the ICF assists in deciding } \\
\text { on an acceptable definition of disability. } \\
\text { - ICF provides a common framework for describing health. } \\
\text { - ICF synthesizes what is appropriate and useful in both the social and } \\
\text { medical models, acknowledging the complex notion of disability as } \\
\text { described in the biopsychosocial model. } \\
\text { - ICF has a multi- dimensional approach, it provides a focus on the } \\
\text { Individual and person Environment. } \\
\text { - ICF can be used to set goals for functional } \\
\text { activities }\end{array}$ & $\begin{array}{l}\text { - The strength of the relationships } \\
\text { between the components is not } \\
\text { addressed (Granlund et al., 2004a). } \\
\text { - Participation cannot be explained } \\
\text { by one or two isolated factors in a } \\
\text { single domain. } \\
\text { - A comprehensive assessment of } \\
\text { an individual, based on the ICF, is a } \\
\text { time- consuming and finely grained } \\
\text { work (Stucki et al., 2002; Grimby, } \\
\text { 2002). } \\
\text { - Activity and participation cannot be } \\
\text { coded separately }\end{array}$ \\
\hline $\begin{array}{l}\text { Granlund } \\
\text { et al., 2008(10) }\end{array}$ & $\begin{array}{l}\text { To discuss the research that } \\
\text { has focused on parents as AAC } \\
\text { interventionists, the family as } \\
\text { a context for AAC intervention, } \\
\text { and the effects of AAC } \\
\text { interventions on children and } \\
\text { other family members }\end{array}$ & 5 & $\begin{array}{l}\text { - The profile can provide a complementary } \\
\text { tool to guide assessment and intervention. } \\
\text { - To plan and organize the goals of AAC interventions }\end{array}$ & \\
\hline $\begin{array}{l}\text { Pless et al., } \\
2012^{(4)}\end{array}$ & $\begin{array}{l}\text { To discuss the implementation } \\
\text { of the ICF and the ICF- CY, } \\
\text { within the context of AAC }\end{array}$ & 5 & $\begin{array}{l}\text { - To enable comparison of data across countries, sectors, time, and } \\
\text { people. } \\
\text { - To offer a common inter- professional language. } \\
\text { - To guide holistic and interdisciplinary } \\
\text { approaches to assessment and intervention }\end{array}$ & $\begin{array}{l}\text { - ICF and ICF- CY are complex } \\
\text { - They may differ from previously } \\
\text { used values and skills. } \\
\text { - Training must be an integral part } \\
\text { of an ongoing process of learning- } \\
\text { by- doing }\end{array}$ \\
\hline $\begin{array}{l}\text { Simeonsson } \\
\text { et al., } 2012^{(9)}\end{array}$ & $\begin{array}{l}\text { To review issues in assessment } \\
\text { and intervention for children } \\
\text { in need of AAC and present } \\
\text { the WHO ICF- CY as a tool } \\
\text { to enhance assessment and } \\
\text { intervention in the AAC field }\end{array}$ & 5 & $\begin{array}{l}\text { - Can be used to approach assessment and intervention efforts in AAC } \\
\text { in an organized and holistic manner. } \\
\text { - The items reflect the multi- dimensional nature of communication and } \\
\text { its expression as the interaction between the individual and the social } \\
\text { and physical environment. } \\
\text { - Common language: the ICF- CY may enhance communication among } \\
\text { professionals, and between professionals and parents. } \\
\text { - To provide uniformity for description of health, } \\
\text { functioning and disability, as well as assessment and intervention. } \\
\text { - The link between intervention planning and assessment organized } \\
\text { by the ICF- CY can focus on promoting children's skills in completing } \\
\text { activities and their participation in important experiences and life } \\
\text { situations }\end{array}$ & $\begin{array}{l}\text { - The strength of the relationships } \\
\text { between the components is not } \\
\text { addressed. } \\
\text { - Participation cannot be } \\
\text { explained by one or two isolated } \\
\text { factors in a single domain }\end{array}$ \\
\hline $\begin{array}{l}\text { Light \& } \\
\text { McNaughton, } \\
2015^{(11)}\end{array}$ & $\begin{array}{l}\text { To apply the framework } \\
\text { proposed by the ICF to } \\
\text { illustrate the need to re- think } \\
\text { AAC intervention to improve } \\
\text { outcomes for individuals with } \\
\text { complex communication needs, } \\
\text { and to foster a new generation } \\
\text { of intervention research that will } \\
\text { provide a solid foundation for } \\
\text { improved services }\end{array}$ & 5 & $\begin{array}{l}\text { - ICF provides a framework that may be helpful considering the holistic } \\
\text { approach in AAC }\end{array}$ & \\
\hline $\begin{array}{l}\text { Wallis, Bloch } \\
\text { \&Clarke, } \\
\text { 201721) }\end{array}$ & $\begin{array}{l}\text { To document AAC training } \\
\text { provision by clinical services } \\
\text { in England }\end{array}$ & 4 & $\begin{array}{l}\text { - ICF is an approach to framing the scope of AAC training. } \\
\text { - ICF can be used to assess communication difficulties and their impact } \\
\text { on daily life for people using AAC. } \\
\text { - ICF uses the biopsychosocial model that examines the interaction } \\
\text { between health conditions, body functions and structures, activities and } \\
\text { participation. } \\
\text { - ICF considers environmental factors }\end{array}$ & \\
\hline
\end{tabular}

AAC- Augmentative and Alternative Communication; ICF- International Classification of Functioning, Disability and Health; ICF-CY- International Classification of Functioning, Disability and Health- version for Children and Youth; WHO- World Health Organization

Figure 4. Description of papers in category ii 


\section{LITERATURE REVIEW}

A total of 67 articles were identified from the electronic searches. Abstracts of all 67 were read; 18 met the inclusion criteria and were reviewed for this paper. Figure 2 shows the study flow diagram with the selection steps. Nine papers drew exclusively on the ICF-CY ${ }^{3,6,9,10,12-16}$, six studies utilized the ICF only 8,11,17-20, and two studies used both frameworks ${ }^{4,5}$.

Figure 3 describes the characteristics of the studies included in Category $\left.\right|^{3,6,12-20}$. Figure 4 describes the characteristics of the studies in Category ii $4,5,8-11,21$.

\section{Category i papers}

In relation to category i papers (used ICF / ICF-CY in the research and/or developed new instruments based on ICF/ICF-CY), seven papers drew exclusively on the ICF-CY,6,12-16, four studies utilized the ICF only ${ }^{17-20}$. Among these papers, only three studies utilized the original frameworks ICF and ICF-CY in the research $6,15,17$. Other researchers developed, validated or used instruments based in the principles of ICF and ICF-CY3,12-14,16,18-20. These instruments are shown in Figure 3.

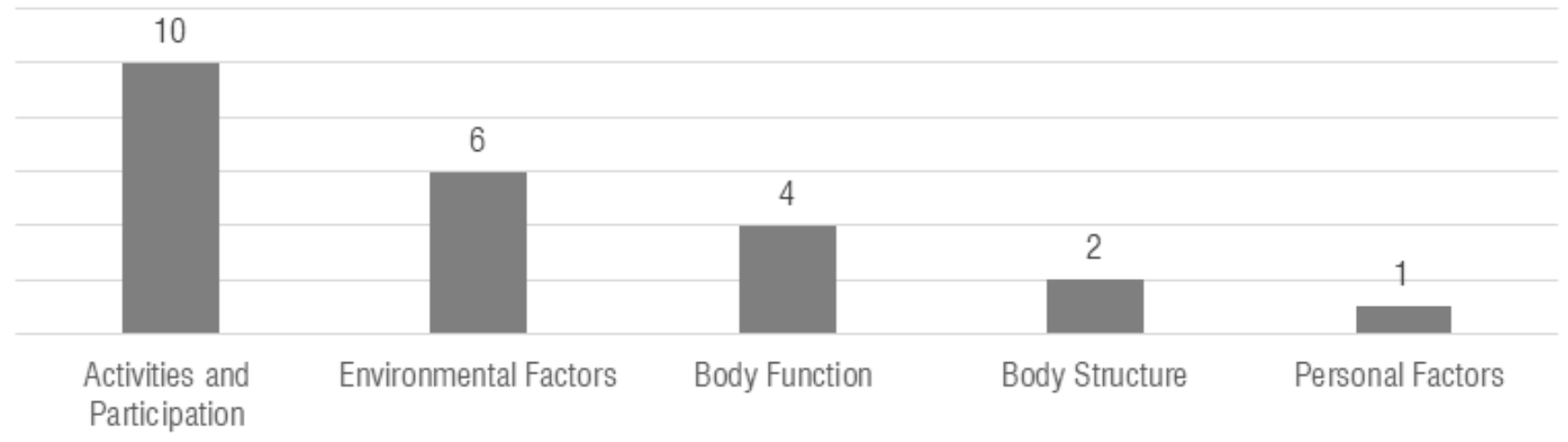

\section{- ICF and ICF-CY components}

Figure 5. International Classification of Functioning, Disability and Health and International Classification of Functioning, Disability and Health- version for Children and Youth components used in papers of category $\mathrm{i}$

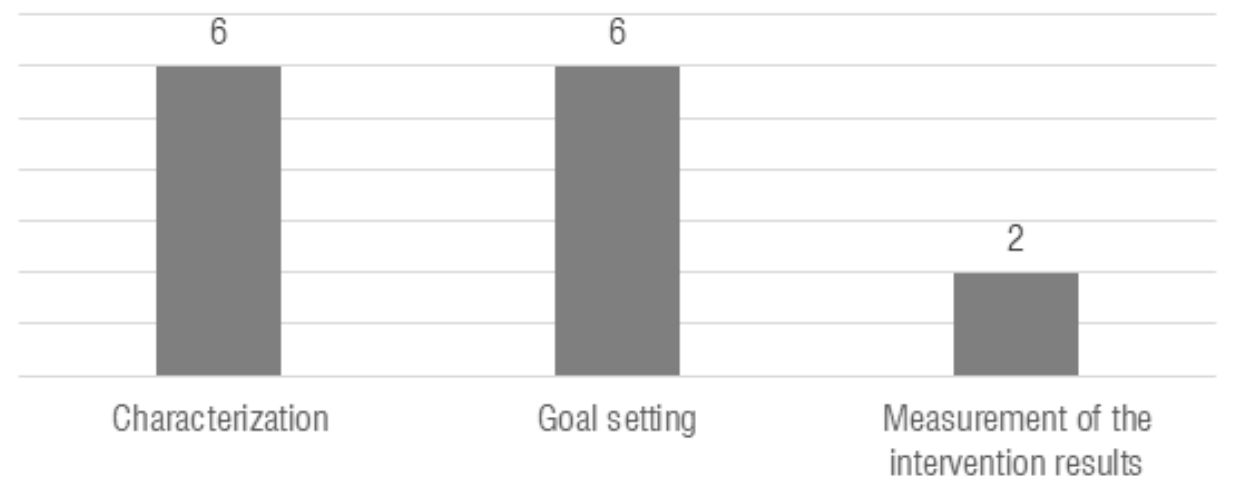

Figure 6. Purpose of using International Classification of Functioning, Disability and Health and International Classification of Functioning, Disability and Health- version for Children and Youth in papers of category $i$

Papers in Category i used the ICF, ICF-CY and the instruments based on them with different purposes, including the characterization of the children and their environment ${ }^{8,12,13,18-20}$, goal setting and measurement of the results of therapeutic intervention ${ }^{3,20}$. Characterization of the children and goal setting were the main uses.
It is important to mention that the articles reported use of all of the ICF and ICF-CY components. However, Activities and Participation was the component most used in the papers. The second most used was the Environment Factors, followed by Body Function, then Body Structure. The least utilized component was 
Personal Factors. Just one article used the qualifiers in the results section ${ }^{20}$.

In category $\mathrm{i}$ papers, a range of stakeholders classified children and their environments according to ICF and ICF-CY frameworks. In papers which we reviewed, parents or caregivers were the people most frequently consulted, followed by the Educators and SLPs, then the client. Other people who were consulted were occupational therapists, physical therapists, physicians and educational specialists. Opinions about children and youth functioning collected through interviews, questionnaires and filling instruments created based in ICF/ICF-CY. Observation and analysis of records were further methods used to classify the domains and items (see Figure 3 for details).

\section{Category ii papers}

Papers grouped under Category ii (theoretical papers) described some advantages, disadvantages and difficulties in using ICF and ICF-CY. ICF and ICF-CY are complex ${ }^{4}$, and consequently, they are time-consuming when used to complete a comprehensive assessment of the individual ${ }^{5,23}$. Notably, description of communication partners is absent from ICF/ICF-CY and consequently this important item of information needs to be characterized as a supplementary item to the ICF / ICF-CY codes $^{8}$. Other categories analyzed by SLPs may not be present in the classifications, so it is important for professionals to understand that ICF and ICF-CY have not replaced professional intervention and analysis.

While the ICF and ICF-CY describe and define the components of which they are composed, and emphasize interaction among domains including particularly between Environmental Factors and the other three components, a weakness is perceived in that the frameworks do not provide a facility to describe the strength of the relationships between items ${ }^{5,9,24}$. Unfortunately, another highlighted problem concerns the operationalization of Participation component. Participation is a complex concept, and is influenced by complex factors including individual characteristics of children, and young, and life circumstances. Because of these factors, participation may vary along the activities, depending on the environmental and personal factors ${ }^{5,25}$. Thus, it is very difficult to use isolated factors to classify clients' participation.

Nevertheless, many advantages of using the ICF and ICF-CY in the AAC field have been reported in the literature. Some of the advantages are described in ICF and ICF-CY user guidelines and were highlighted in the papers ${ }^{4,5,8-10,11,21}$. The first is to provide a biopsychosocial model to describe the disability. The second is to offer a common language between different types of professionals and between professionals and family, thus these advantages may improve the communication between them. The third is the description that one component can influence another, and all components together can describe the clients' functioning. Finally, both frameworks enable comparison of data across time, countries, services, and people ${ }^{1,2}$.

Advantages directly related to the AAC field were described too. The first advantage is that the ICF and ICF-CY contain important domains for the characterization of the people who rely on AAC and their environment, reflecting the complexity of communication, such as: availability of AAC system; attitudes toward assistive communication devices; receptive and expressive language; interaction; pragmatic skills; vocabulary selection; visual demands; motor demands; auditory demands; and interaction with people ${ }^{5,8,9}$. Second, the ICF and ICF-CY provide a focus on clients' Environment, thus frameworks can be used to set goals for functional activities and to facilitate a person oriented intervention ${ }^{5}$. Third, the holistic approach in AAC that can be facilitated by the use of ICF and ICF-CY4,9,21. Finally, there is a link permitted by ICF and ICF-CY between the assessment and intervention goals, because professionals can focus on promoting clients' skills in significant activities and their participation in important life situations ${ }^{9}$.

To date, only a handful of papers have been published documenting the application of the ICF and ICF-CY in the AAC field. Some factors which have potentially limited their application are that they are time consuming ${ }^{4,5,23}$, the complexity of the process ${ }^{4}$, a lack of familiarity about these frameworks, a lack of familiarity with biopsychosocial models ${ }^{4}$, and little or inadequate training in how to use the ICF and ICF-CY ${ }^{4}$. However, the published articles have shown that there are many possibilities, proposals and advantages in using ICF and ICF-CY in the AAC field.

ICF and ICF-CY and other instruments based on them have been used with different purposes in many aspects of AAC implementation, such as: characterization of the children and their environment, goal setting, evaluation of intervention outcomes and effectiveness of AAC. The publications reviewed for this paper indicate that, in the AAC field, ICF and ICF-CY have been used across the entire therapeutic process, 
guiding professionals in assessment, goal setting, intervention and evaluation of intervention outcomes. Consequently, in principal at least, the standardized language of the ICF can uniform and unify the terms used in descriptions of the therapeutic process and thus offer potential for direct comparison between studies, types of clinical interventions and, arguably, between services $^{1,2}$. This type of information can generate databases that will support public policy development and potentially increase the investment in the AAC field.

The ICF components most frequently drawn on in AAC research are Environmental Factors, and Activities and Participation. This may reflect a broader shift in the AAC field away from assessment and intervention concerned with the 'impaired body' to other factors related to environment, activities and participation of the client. This change is important because it reflects a recognition that communication does not depend only on the body's function and structure. Rather, communication happens in social activities and is influenced by environmental factors, such as attitudes, availability of devices, and policies. Thus, the use of ICF and ICF-CY allows professionals to focus on the integration of skills to maximize communication to focus on the individual's participation in real-world contexts, and to attend to environmental factors related to the individuals who require $A A C^{11,21}$. Given this complex scenario that makes up communication, ICF and ICF-CY are frameworks that contain relevant components for the AAC field.

Because communication happens among people, it is important to hear from people who participate in the social circle of the client. People who were consulted to aid classification of the ICF, ICF-CY and instruments based on them, included parents, caregivers, client and a range of professionals $\mathbf{s}^{3,6,12-17,19,20}$. The Appendix of ICF-CY itself highlights the importance of involving clients and their caregivers using the framework ${ }^{2}$. The active participation of clients and their families in the therapeutic process, informing their difficulties and opinions about the AAC implementation, may facilitate AAC adhesion in daily life, with information about: the use of SGDs, the identification of critical barriers and facilitators to communication, participation in social activities at school, at home, and other activities usual for the client's age $3,6,12,13,18,19$. Thus, the ICF-CY enshrines the ethos of professional and client consultation in decision-making.

ICF and ICF-CY allow professionals to expand the concept of participation, which is an important concept for communication and AAC ${ }^{5}$. ICF and ICF-CY differentiate the activity concept from participation concept, and this differentiation is useful in the AAC field because to have access to an activity is different from taking part in this activity. Papers have investigated interesting themes in this component, such as who participates more in activities (children or adolescents) ${ }^{12}$; what is the difference between the activity and participation among children with physical disabilities and complex communication needs, children with physical disabilities only, and children with typical development ${ }^{13}$; and changes in this component after intervention and AAC implementation ${ }^{19,20}$. In possession of information about activities and participation, professionals can maximize the use of $A A C$ and can support the client participation in daily activities.

Other factors that can influence communication are the Environmental Factors. Some domains in Environmental Factors which are interesting to AAC professionals are attitudes of others, the lack of speech pathology and educational services, and having access to AAC devices. Importantly, the ICF and ICF-CY provide the opportunity to code Environmental Factors as barriers and facilitators, which influence functioning ${ }^{5,6}$. Thus both positive and negative factors are recognized to influence health and functioning. Consequently, interventions that focus on the individual in their environment may seek to enhance further environmental facilitators as well as dismantle barriers ${ }^{5}$.

Other advantages of using ICF and ICF-CY in the AAC field is the optimization in activity and participation $^{6}$. By identifying environmental barriers and facilitators, professionals can use strategies to optimize a client's activities and participation and reduce the effects of the barriers. Thus, with all this knowledge, the goal setting can be person-centered and professionals can focus the intervention on relevant environmental factors and relevant situations for clients, enabling a more functional approach to management.

ICF and ICF-CY have shown many advantages when used in the AAC field. Because it is a complex model it has been recommended that professionals undergo training in its use ${ }^{4}$. Pless \& Granlund ${ }^{4}$ have discussed examples of training in different services and countries and have provided directions for training and implementation of the ICF and ICF-CY in AAC services. Some directions recommended were to: establish clear goals for training; prepare the training; involve all participants in training; know the theoretical model and professional trajectory of participants; relate the biopsychosocial 
model in the ICF and ICF-CY to the existing individual and organizational perspectives; discuss how to classify and apply frameworks; provide feedback to participants about the effects of training ${ }^{4}$. With trained professionals, the use of the ICF and ICF-CY in AAC services will be more efficient and all resources of these frameworks might be better explored.

One topic proposed in the professionals training is how to apply ICF ${ }^{4}$. Papers utilized ICF and ICF-CY in different ways, such as domains, code-set and tools elaborated based in ICF principles in the researches ${ }^{3,6,12-14-20}$. These different proposals to apply the biopsychosocial model are important because they reflect attempts to incorporate ICF and ICF-CY principles in to the clinic routine. It may not be easy for professionals to start using these frameworks because of the ICF and ICF-CY complexity, thus using a limited set of codes can simplify the application use ${ }^{4}$. It is also indispensable that professionals comprehend ICF and ICF-CY, their theoretical models, their components, and the possibility to classify domains that are not in the code-set or other tools, but can still be useful to clients.

Another important result to discuss has to do with the use of qualifiers. Qualifiers have an essential role in many ICF and ICF-CY's objectives, especially in objectives related to formation of databases and data comparison between countries, time and services. However most selected papers did not describe the qualifiers in their sections. An ICF and ICF-CY category can only be called a code when a qualifier is used, so papers that did not use qualifiers failed to use the classifications in its entirety, as a codification system. One reason why qualifiers have not been used can be the difficulty in classifying them, because ICF and ICF-CY do not establish parameters about what to consider a mild or a complete difficulty in each domain. Another reason can be the amount of time necessary for professionals to classify the qualifiers. Despite these reasons, it is important to understand why qualifiers have not been used and to adequately explain the importance of their use for professionals. If professionals do not use qualifiers, some ICF resources will never be explored.

\section{CONCLUSION}

Our integrative research review showed that the authors have used both frameworks (ICF and ICF-CY) in studies including children and youth. The authors have utilized the original frameworks ICF and ICF-CY, but they also have used modifications of these frameworks with the purpose of elaborating other instruments based on them.

The results show that ICF and ICF-CY have been used across therapeutic processes, including the characterization of the children and their environment, goal setting and measurement of the results of therapeutic intervention. Besides the use of frameworks in different steps of the intervention process, all ICF and ICF-CY's components have been addressed. The components which have been the most frequently applied ones are the Environmental Factors and Activities and Participation.

Different people have been consulted to classify the frameworks' domains and instruments based on them, including parents, caregivers, clients and professionals in different areas. The active participation of clients and their families in the therapeutic process is important because it may influence AAC adhesion, the use of SGDs, the identification of barriers and facilitators of the aspects of communication, participation in social activities at school, at home, and other activities usual for the age.

ICF and ICF-CY showed many advantages if used by professionals, but some factors have hampered the use of ICF and ICF-CY. Some factors are that WHO's frameworks are relatively new and implementation takes time; a lack of familiarity with these frameworks; a lack of familiarity with the biopsychosocial model; and few or inadequate training on how to use the ICF and ICF-CY. However, the published articles have shown that there are many possibilities, proposals and advantages in using ICF and ICF-CY in the AAC field. WHO's frameworks provide a biopsychosocial model to describe the disability, offer a common language between different types of professionals and between professionals and family, contain important domains for the characterization of the people who rely on AAC and their environment, and provide uniformity for the clients' description in all clinical processes, such as assessment, goal setting, intervention and measurement of its outcomes.

Thus, the ICF and ICF-CY's biopsychosocial models have permitted that the focus for AAC assessment and intervention may be the client, family, communication, the environment, and the interactions among them. However, more professionals' training on how to use these frameworks is necessary to implement them in the services. 


\section{REFERENCES}

1. ICF International Classification of Functioning, Disability and Health. Geneva: World Health Organization; 2001.

2. ICF-CY International Classification of Functioning, Disability and Health, Children and Youth version. Geneva: World Health Organization; 2007.

3. Delarosa E, Horner S, Eisenberg C, Ball L, Renzoni AM, Ryan SE. Family impact of Assistive Technology Scale: development of a Measurement Scale for Parents of Children with Complex Communication Needs. Augmentative and Alternative Communication. 2012;28(3):171-80.

4. Pless M, Granlund M. Implementation of the International Classification of Functioning, Disability and Health (ICF) and the ICF Children and Youth version (ICF-CY) within the context of Augmentative and Alternative Communication. Augmentative and Alternative Communication. 2012;28(1):11-20.

5. Raghavendra P, Bornman J, Granlund M, BjorckAkesson E. The World Health Organization's International Classification of Functioning, Disability and Health: implications for clinical and research practice in the field of augmentative and alternative communication. Augmentative and Alternative Communication. 2007;23(4):349-61.

6. Mei C, Reilly S, Reddihough D, Mensah F, Green $J$, Pennington $L$ et al. Activities and participation of children with cerebral palsy: parents perspectives. Disability and Rehabilitation. 2015;37(23):2164-73.

7. ICD 10 International Statistical Classification of Diseases and Related Health Problems. Geneva: World Health Organization; 1992.

8. Pennington L, Marshall J, Goldbart J. Describing participants in AAC research and their communicative environments: Guidelines for research and practice. Disability and Rehabilitation. 2007;29(7):521-35.

9. Simeonsson RJ, Bjorck-Akesson E, Lollar DJ. Communication, Disability, and the ICF-CY. Augmentative and Alternative Communication. 2012;28(1):3-10.

10. Granlund M, Bjorck-Akesson E, Wilder J, Ylven R. AAC Interventions for children in a family environment: implementing evidence in practice. Augmentative and Alternative Communication. 2008;24(3):207-19.

11. Light J, McNaughton D. Designing AAC Research and Intervention to Improve Outcomes for Individuals with Complex Communication Needs.
Augmentative and Alternative Communication. 2015;31 (2):85-96.

12. Clarke M, Newton C, Petrides K, Griffiths T, Lysley A, Price K. An examination of relations between participation, communication and age in children with complex communication needs. Augmentative and Alternative Communication. 2012;28(1):44-51.

13. Raghavendra P, Olsson C, Sampson J, Mclnerney $\mathrm{R}$, Connell T. School participation and social networks of children with complex communication needs, physical disabilities and typically developing peers. Augmentative and Alternative Communication. 2012;28(1):33-43.

14. Rowland C, Fried-Oken M, Steiner SAM, Lollar D, Phelps R, Simeonsson RJ et al. Developing the ICF-CY for AAC profile and code set for children who rely on AAC. Augmentative and Alternative Communication. 2012;28(1):21-32.

15. Rowland C, Fried-Oken M, Bowser G, Granlund M, Lollar D, Phelps $R$ et al. The Communication Supports Inventory-Children \& Youth (CSI-CY), a new instrument based on the ICF-CY. Disability and Rehabilitation. 2016;38(19):1909-17.

16. Klang N, Rowland C, Fried-Oken M, Steiner S, Granlund M, Adolfsson M. The content of goals in individual educational programs for students with complex communication needs. Augmentative and Alternative Communication. 2016;32(1):41-8.

17. Bornman J, Murphy J. Using the ICF in goal setting: Clinical application using Talking Mats. Disability and Rehabilitation: Assistive Technology. 2006;1(3):145-54.

18. Hidecker MJ, Paneth N, Rosenbaum PL, Kent $\mathrm{R}$, Lillie J, Eulenberg JB et al. Developing and validating the Communication Function Classification System for individuals with cerebral palsy. Developmental Medicine \& Child Neurology. 2011;53(8):704-10.

19. Bunning K, Gona JK, Newton CR, Hartley S. Caregiver perceptions of children who have complex communication needs following a home-based intervention using Augmentative and Alternative Communication in rural Kenya: an intervention note. Augmentative and Alternative Communication. 2014;30(4):344-56.

20. Romano N, Chun RYS. Condições linguísticocognitivas de crianças usuárias de comunicação suplementar e/ou alternativa segundo componentes da CIF. Distúrb. Comun. 2014;26(3):503-18. 
21. Wallis S, Bloch S, Clarke M. Augmentative and alternative communication (AAC) training provision for professionals in England. J. Enabling Technol. 2017;11(3):101-12.

22. Oxford Centre for Evidence-Based Medicine. Levels of evidence [Internet] 2009 [viewed 01 jul 2020]. Avaiable from: https://www.cebm.net/2009/06/ oxford-centre-evidence-based-medicine-levelsevidence-march-2009/

23. Stucki G, Ewert T, Cieza A. Value and application of the ICF in rehabilitation medicine. Disability and Rehabilitation. 2002;24(17):932-8.

24. Granlund M, Eriksson L, Ylven R. Utility of international classification of functioning, disability and health's participation dimension in assigning ICF codes to items from extant rating instruments. J Rehabil Med. 2004;36(3):130-7.

25. Imms C, Adair B, Keen D, Ullenhag A, Rosenbaum P, Granlund M. 'Participation': a systematic review of language, definitions, and constructs used in intervention research with children with disabilities. Dev Med Child Neurol. 2016;58(1):29-38. 